\title{
The Principal Leadership in Strengthening Elementary School Education Character
}

\author{
Juharyanto \\ Department of Educational Administration \\ State University of Malang \\ juharyanto.fip@um.ac.id
}

\author{
Ahmad Yusuf Sobri \\ Department of Educational Administration \\ State University of Malang \\ ahmad.yusuf.fip@um.ac.id
}

\author{
Ahmad Nurabadi \\ Department of Educational Administration \\ State University of Malang \\ ahmad.nurabadi.fip@um.ac.id
}

\begin{abstract}
This study aimed to describe the character values developed, the management of character education, and the principal leadership in empowering the elementary school character. The research used a qualitative with multisite design. Data was collected through snowball sampling through interviews, observation and documentation. The findings of this study are: (1) the value of the characters developed are religious, nationalist, independent, mutual cooperation and integrity' (2) the management of character education includes: planning, organizing, implementing and supervising and evaluating; and (3) in empowering the students character, the principal made themselves as being a motivator for his subordinates, creating a conducive school climate and culture, and being good models.
\end{abstract}

Keywords: school principal leadership, character education management, character education strengthening

\section{INTRODUCTION}

Currently the problem of character has been talking and discussing a lot, especially young people. Some of the recent events that have been hectically spoken are acts of violence, brawls, drug addiction, murder, rape. School is one of the effective institutions to instill character values to young people. Therefore, the government publishes a school manual for the Development of National Cultural and Character Education [1].

Good and conducive school culture will support every individual in educational institutions. Lickona stated that the destructive and irresponsible actions of young people, such as crime, drug use, and premarital sexual behavior are caused by the absence of good character [2], [3]. In the world of education, educators have made a lot of efforts to overcome unfavorable behavior in their students [4], for example, tightening rules and supervision, regulating the proportion of students and the number of classes, teaching how to overcome conflicts and relationships.

But all that often has not been successful and the students still show behavior that is not in line with expectations. This can happen because the moral side is often forgotten in education. The appreciation of the values of life is the basis for the formation of human character. Therefore, it is appropriate that character education is a central issue for the educational process carried out in schools at all levels. Character education must be believed to be a continuous process through awareness and habituation. Local wisdom must be the main reference in implementing character education [5].

Education that is oriented towards character development is based on the perspective that students are seeds that have diverse potential advantages. They are not uniform or similar seeds, and instead consist of individual differences with one another from which their creative potential is sourced. Good character is a requirement for the competency a person has to use wisely [6]. Competency will become wealth and benefit many people if the competency is accompanied by good character.

There are three key words that need attention in managing character education in schools, namely views, values, and virtue (opinions, values and virtues). The actual education unit has so far developed and implemented character building values through the operational program of each education unit. Schools should develop character values in order to improve the quality of students who will improve the quality of the school [8]. In order for character education to succeed, the management of character education should be carried out in accordance with the management process.

The success of the school in implementing what has been planned or organized needs to be supported by the leadership skills of a school principal. A school principal should be able to manage all the resources in his school so that his school can develop forward from time to time. Therefore, all available resources must be utilized in such a way [9]. In order for the school to be led to run effectively, the principal needs to move teachers effectively, and good relations between them are fostered so as to create a positive, exciting and productive work atmosphere.

Some research shows that leadership orientation that emphasizes people tends to be more effective and several other studies show that leadership orientation that emphasizes the task is more effective [10], [11]. The role of the principal in the management of character education in schools is very strategic. This is due to the principal being the main driver in the implementation of the planned program. How do principals manage character education so that the values in character education are embedded in students in school? 
The first element that must be a concern for the development of character education in schools is to develop academic excellence. Since children enter school, from playgroup, kindergarten, elementary school to university, the main mission of educational institutions is to develop the potential of students as good learners [12]. Therefore, promoting the virtues associated with good learners is essential for character formation.

\section{METHODS}

Bogdan and Biklen states that tTo answer the problem of research comprehensively, the approach used is qualitative [13]. Researchers act as key instruments as well as data collectors. The research design uses sociological phenomenology research with multi-site design, where the design can be used primarily for the development of theories raised from the background of the study [14], [15].

Research data sources consist of two types: (1) human beings, namely key informants who understand character education programs, namely principals, teachers, school committees and parents of students; and (2) non-human, namely literature and various printed materials about leadership headmaster, value of character education, and management of character education. Data collected through snowball sampling with interviews, observation and documentation techniques [16]. This research was conducted at SDN Rampal Celaket 2 and SDN Tunjungsekar 1 Malang City.

\section{RESULTS \\ Developed Character Values}

Although the Ministry of National Education in 2009 issued a guide to character values intended for elementary schools throughout Indonesia with the title: Values and Descriptions of Values of Cultural Education and National Character, but SDN Rampal Celaket 2 Kota Malang has determined the fivecharacter values to be distributed to students start in 2017. This is in accordance with what has been announced by the Government in order to implement the main values of the National Movement for Mental Revolution, which includes: religious, nationalist, independent, mutual cooperation and integrity.

In order to streamline predetermined character values, the principal and the teacher council design programs to support these character values. Each character value has a support program. First, is religious value. The supporting program is imtaq (believe and faith) held on every Morning Friday which is attended by all school residents; extracurricular recitation, the art of reciting and memorizing Al Quran; morning assembly activity by reading asmaul husna (the 99 devine names of Allah) and ending the prayer together; social service to an orphanage; istighosah / dzikrullah (remembering Allah through reciting His Devine names) for sixth grade only; prayer congregation; fulfilling the Mosque tools and medias; Islamic Commemoration Days; repairing and fulfilling the Mushola tools and medias; the place for taking ablution repairmen.
Second, the values of nationalism. There are several supporting programs to realize the nationalist values of students, namely: carrying out routine flag ceremonies every Monday and national days; Morning apples are held every Tuesday, Wednesday and Thursday with all students, teachers, principal and employees being followed; commemoration of national holidays; Scout extracurricular activities, choir, batik; participate in competitions to improve superior performance.

Third, independent values. Independent children's value planting is designed with several supporting programs, including: cooperation in complying with rules, discipline in each class and school so that parents understand more about the rules and rules of karma at school; familiarize children with a healthy lifestyle in eating and drinking in an orderly manner, training children to take care of themselves starting from dressing neatly and politely; equip children by giving counseling habituation without being told; culture on time; Salim (shaking hands in Islamic version) culture after the ceremony; Salim culture when it comes to being welcomed by the teacher; feeling of shy for negative thought and action culture (embarrassed to come late, to cheat, to violate, not working on homework); reading movement; having lunch together with the aim of educating children to be independent, learning to appreciate the left over food and the culture of queuing when taking food.

Fourth, the value of mutual cooperation. Habitual mutual cooperation is carried out with several supporting programs, namely: the constructing the Green and Clean school environment that is focused on clean class agenda; Class picket; involve the committee in school activities; involving students' parents, Business and Industry as well as Alumni in school progress; activate / include community participation; track alumni for school development; establish relationships with other relevant parties.

Fifth, the value of integrity. The integrity value support program carried out at SDN Rampal Celaket 2, Malang City, includes: honesty canteen; increasing orderly and disciplined culture; establish the role of parties related to the realization of a healthy canteen; the activities of school citizens create order and discipline in the environment; habituation 5 (smile, greetings, greetings, polite, polite); coaching about noble character.

The other school, Tunjung Sekar 1 State Primary School in Malang City in determining PPK also refers to the main values of the National Movement for Mental Revolution that has been proclaimed by the government. Character values in question are religious, nationalist, independent, mutual cooperation and integrity.

Each of the predetermined character values is further elaborated in several supporting activities. In order for the support activities to get support, the principal held a meeting with the teacher to design the activity. First, is religious value. The supporting program is a program of faith and piety which is implemented with Dhuhur prayer congregation every day and Friday Prayers for male students; 
extracurricular on the art of reciting and memorizing $A l$ Quran; every morning asmaul husna; dzikrullah (remembering Allah through reciting His Devine names); commemorating religious holidays.

Second, the values of nationalism. To support national values, schools have programmed supporting activities, namely routine flag ceremonies every Monday and national days; singing national songs every day; commemoration of national holidays with various competitions; choir; Scout extracurricular activities.

Third, independent values. Planting the value of independence for children is designed with several supporting programs, including: cooperation in doing work; comply with all school rules; familiarize discipline in learning; familiarize children with a healthy lifestyle; independent in preparing various school needs.

Fourth, the value of mutual cooperation. Habitual values of mutual cooperation are carried out with a number of supporting programs, namely: creating a clean and green school environment, class cleanliness through class pickets, involvement of parents and alumni in developing schools, and establishing relationships with other parties that can support school progress.

Fifth, the value of integrity. Supporting programs in order to instill the values of integrity carried out by the school include: increasing the orderly culture and discipline in each activity; the creation of an honesty canteen; customizing courtesy at school and home; and coaching noble character for each student.

\section{The Management of Character Education}

Management of character education includes: planning, organizing, implementing and monitoring and evaluating. Each will be discussed in detail as follows. Planning of character education at SDN Rampal Celaket 2 Kota Malang as a PPK piloting school began with holding workshops and socialization of PPK in schools with the aim to provide understanding to teachers and education personnel. The activity was then followed up with the establishment of supporting programs and the establishment of a development team. The results of the workshop and socialization were then submitted to the school committee and student guardians.

The next activity was the organization of the PPK program, namely the division of the team and the organizational structure of the PPK program implementation. These activities include: (1) the selection of a team or person in charge and executor; (2) description of the division of tasks for each part of the team; and (3) a certificate which becomes an official document of the organizational structure of the activity. The team consisted of school supervisors, principals, teachers and school staff and school committees.

The next stage is the implementation of PPK activities. The activities are carried out in accordance with the programs that have been programmed at the planning stage, especially in terms of habituation carried out every day for five school days. These activities include: flag ceremonies every Monday; morning apple activities every Tuesday, Wednesday and Thursday; imtaq (believe and faith) and istighosah / dzikrullah (remembering Allah through reciting His Devine names) activities; congregational prayer activities; Friday prayer activities for men and Dhuhur prayer together for women; and extracurricular support of PPK. Every activity carried out has been arranged by the person in charge and the schedule with the aim that the implementation runs regularly and there is no clash of coaching schedules with other teachers.

The next step is supervision and evaluation. At this stage, the principal and the person in charge of the activities carry out supervision and assessment, and make improvements to the implementation of PPK. Supervision and evaluation is carried out on all activities carried out every week, month, and the last is at the end of the semester through meetings. While monitoring from the supervisor is conducted every month to see the development of the PPK program in schools that are under its guidance.

Almost similar to the previous school phenomena above, planning of character education at Tunjungsekar 1 Elementary School in Malang City begins with socialization to all teachers and education personnel. This school is one of the piloting schools of the PPK program in Malang City so the PPK program must be better than other schools. After that, the school held a workshop to determine various support programs in order to succeed the PPK program. The results of the workshop were then socialized to the school committee and all student guardians.

The next stage of the management process is the organization of the PPK program, namely the division of the team coordinator and the creation of the PPK program organizational structure. These activities include: division of each program coordinator responsible for the success of the program and its members; a description of the division of tasks for each part of the activity coordinator and members; and the making of the organizational structure of activities. The team consisted of school supervisors, principals, teachers and school staff and school committees.

The next management process is the implementation or implementation of the PPK program. The activities are carried out in accordance with the predetermined program that will be carried out every day for five school days, for example the flag ceremony every Monday; dhuhur prayer activities in congregation; imtaq (believe and faith) and istighosah dzikrullah (remembering Allah through reciting His Devine names) activities; and extracurricular support of PPK. Every activity carried out has been arranged by the person in charge and the schedule with the aim that the implementation runs in an orderly manner.

The last management process is supervision and evaluation. In this activity, the principal is in charge of all activities programmed and in charge of each activity to supervise and evaluate, and make improvements to the implementation of PPK. Program monitoring and evaluation is conducted every week, month, and at the end of the semester through meetings. Every month the supervisor monitors the course of the PPK program in the target schools. This is done to find out the achievement of the PPK program in each region. 
Principal Leadership in Strengthening the Character Education

The role of the principal is crucial in the success of the PPK program. In carrying out his leadership, the Head of SDN Rampal Celaket 2 Malang City has a firm and disciplined attitude in implementing the rules or regulations that apply in schools. In addition, to support the program that has been established, the school principal involves all school residents both teachers, education staff and students. The program run by the principal can run well if the principal is able to be a motivator for his subordinates in carrying out their duties. This motivation is carried out by providing great support for the tasks charged to the teacher.

In addition to supporting school programs, the principal creates a conducive school climate and culture. The creation of the school's climate and culture will have an impact on subordinates' commitment in carrying out their duties. Every school citizen is committed to carrying out his duties, both principals, teachers, education staff and students. The commitment of the school community is realized in the form of formulating the school's vision and mission and also making display boards. The purpose of the display board is for all school residents to always remember it.

In order for the PPK program activities to run effectively, there is a need for models and examples from the principal in carrying out their duties. This model and exemplary become a big capital in influencing subordinates so that they are moved to do positive things. Different from the school above, the Head of Tunjungsekar 1 Elementary School in Malang City has a disciplined and firm attitude in carrying out all the rules in school. This has implications for the achievements of the programs that have been implemented, including the PPK program.

As a leader, the principal has the responsibility to give full support to the teacher's duties. Therefore, the Head of Tunjungsekar 1 Elementary School in Malang City always gives positive encouragement to the teacher in carrying out his work, especially for the success of the PPK program.

The planned program will succeed if the principal as a leader is able to create a school climate and culture that is conducive to his subordinates. The creation of a conducive school climate and culture has been carried out by the Head of Tunjungsekar 1 Elementary School in Malang City and has an impact on the subordinates' commitment in carrying out their duties. Subordinate commitment is needed for the success of the planned program.

Various activities to support the PPK program will run effectively, if there is an example from the principal as a leader. Exemplary principals become models for teachers in doing their work. Exemplary principals can influence teachers to do what they are responsible for.

\section{Developed Character Values \\ IV. DISCUSSION}

The character values developed by SDN Rampal Celaket 2 and SDN Tunjungsekar 1 Malang
City as a piloting school for the Strengthening Character Education (PPK) program refer to the main values of the National Movement for Mental Revolution that has been proclaimed by the government. Character values in question are religious, nationalist, independent, mutual cooperation and integrity. According to the Republic of Indonesia Ministry of Education and Culture (2017) strengthening character education is an educational program in schools to strengthen the character of students through harmonization of heart processing, sense processing, thought processing, and sports with the support of public involvement and cooperation between schools, families and communities which are part of the National Movement for Mental Revolution (GNRM).

The PPK program being launched by the government is actually a continuation of the government in 2010, in which the government has issued a school manual for the Development of National Cultural and Character Education [17] which contains eighteen characters that can be distributed to students at school. The guidelines describe various kinds of background of thought, principles and approaches, assessment criteria, and their implementation. The contents of the school guidelines actually discuss more about the class-based character education approach.

Comparing between the 2017 PPK guidelines from Ministry of Education and Culture and the 2010 PPK Ministry of National Education guidelines, there are some similarities, only a few are different, for example nationalist values can be equated with the value of patriotism, the value of mutual cooperation can be equated with friendly / communicative values, and integrity values can be equated with value of responsibility. Each of these character values can be described as follows, namely: (1) religious values, namely attitudes and behaviors that are obedient in carrying out the teachings of the religion he adheres to and live in harmony with adherents of other religions; (2) the value of love for the homeland, namely the way of thinking, behave, and act that shows high loyalty, caring and respect for the language, physical environment, social, cultural, economic and political nation; (3) independent values, namely attitudes and behaviors that are not easily dependent on others in completing tasks; (4) friendly / communicative values, namely actions that show pleasure in talking, socializing, and working with others; and (5) the value of responsibility, namely the attitude and behavior of a person to carry out their duties and obligations, which should he did, to himself, the community, the environment (natural, social and cultural).

The cultivation and seeding character values for children will work well if there is a good and conducive school culture that supports individual behavior in schools [18]. The destructive and irresponsible actions of young people, such as crime, drug use, and premarital sexual behavior are caused by the absence of good character [19]. In the world of education, educators have made a lot of effort to overcome unfavorable behavior in their students [4], for example, tightening rules and supervision, regulating 
the proportion of students and the number of classes, teaching how to overcome conflicts and relationships.

Identification of basic character values is important so that moral moral distortions do not occur; the base becomes derivative and vice versa, the derivative value is used as a principal value. Pro-life attitudes, including positive attitudes toward the environment are derivatives of the value of caring. Children who care for each other, for their health, for those who are less fortunate, of course basically also care for the life of plants, animals and the planet where they live. Anti-violence attitude is a derivative of the value of honor. A child who feels honored and dignified will certainly not commit violence against his friends, animals, and environment [20].

The values of the original character include: honesty, fairness, honor, care, responsibility and citizenship. However, due to the influence of culture and religion, there are several values which according to certain groups are basic, while others classify other values as basic virtues [2]. For example, "hard work" is considered a basic value in a particular culture, and "struggle" is a fundamental value in another group. There are six-character traits that children must learn, namely faith, integrity, calmness, self-discipline, endurance, and courage [21].

\section{Management of Character Education}

The PPK program that has been proclaimed by the Ministry of Education and Culture will run effectively and in accordance with the objectives, it needs to be managed properly. Management of character education should be carried out in accordance with the management process as stated by several experts. Management is the process of carrying out various activities within the framework of the application of objectives and as the ability or skill of people who hold managerial positions to obtain an outcome in order to achieve goals through other people's activities [22], [23]. Management is a different process consisting of planning, organizing, actuating, and controlling that is done to achieve the goals determined by using humans and other resources [24].

Cultivating character values to students through the PPK program in both schools which are the background of the study following the management process that has been put forward by these experts. The two schools that are the background of the study carry out the management process by following the steps: planning, organizing, implementing, monitoring and evaluating [2].

PPK program planning begins with socialization and workshops and is followed up with the establishment of supporting programs. Organizing the PPK program is done by dividing the team, the person in charge and the job description and the formation of the organizational structure. The implementation of the PPK program is carried out in accordance with program planning. Supervision and evaluation of the PPK program is carried out periodically, starting weekly, month and semester conducted by school principals and school supervisors.

\section{Principal Leadership in Management of Character Education}

Leadership is essentially a core function in the management process. School success is inseparable from the principal's leadership roles and abilities. The school principal should be able to manage all the resources in his school to progress. Effective principals can move teachers and good relations between them to be fostered to create a positive, exciting and productive work atmosphere so as to foster creativity, discipline and high learning spirit for students.

The existence of the principal as a leader is very important because it is a driving force for all school personnel. So big is the role of the principal in the process of achieving educational goals, so that the success or failure of school programs is largely determined by the quality of leadership held by the principal [25], [26]. The success of a leader carrying out his duties is more determined by his ability to choose and use his leadership style that is appropriate to the situation and condition of the person being led.

The role of the principal as a leader appears in an effort to influence his subordinates to carry out tasks with enthusiasm for the achievement of educational goals. The important role of school principals as leaders is: (1) statesperson (state expert), educational leader (education leader); (3) supervisory leader (staff coach); (4) organizational leader (leader organization); (5) administrative leader; and (6) team leader (group leader or team leader) [27]. Whereas Duignan (2004) states that effective principals have a variety of adequate capabilities, including: educational capabilities, personal capabilities, relational capabilities, intellectual capabilities, and organizational capabilities (organizational capabilities) [28].

The role of the principal at this time is very important especially in overcoming the moral problems of the nation's children. How a school principal can design a program that can counteract the moral decadence that has become more widespread lately, such as brawls, drugs, truancy, murder and other acts of violence. The role of the principal in the management of character education in schools is very strategic. This is due to the principal being the main driver in the implementation of the planned program. How do principals manage character education so that the values in character education are embedded in students in school?

As a leader, a school principal should create a good and conducive school culture that will support each individual in the educational institution he leads. School culture is the fabric of relationships and interactions between members of the school community that breeds spontaneity, habituation, celebrations and traditions that form stable behavioral habits for each member of the school environment [29].

According to the Ministry of National Education school culture is the life of the school where students interact with each other, teachers with teachers, counselors with each other, administrative staff with each other, and among members of the school community group. School culture is formed from the interaction and communication between individuals in 
the school community [17]. Interaction and communication form social structures and norms that apply in the educational environment. These rules and social norms are needed because the relationships and interactions within educational institutions are more determined by the definition of roles in accordance with the existing rules. The success of creating a good school culture is more determined by the principal in managing the diverse behaviors found in the school environment.

\section{CONCLUSION}

Based on the results of the study, it can be concluded: (1) the character values developed by these two schools refer to the main values of the National Movement for Mental Revolution which has been proclaimed by the government. The character values are religious, nationalist, independent, mutual cooperation and integrity; (2) the management of character education includes: planning, organizing, implementing and monitoring and evaluating. PPK program planning begins with socialization and workshops and is followed up with the establishment of supporting programs. Organizing the PPK program is done by dividing the team, the person in charge and the job description and the formation of the organizational structure. The implementation of the PPK program is carried out in accordance with program planning. The supervision and evaluation of the PPK program is carried out periodically, starting weekly, month and semester conducted by school principals and school supervisors; (3) the principal's leadership of the success of the PPK program is carried out with firmness and discipline in implementing regulations, being a motivator for his subordinates, creating a climate and a conducive school culture, and models and examples for his subordinates.

\section{REFERENCES}

[1] Kemendiknas, Pengembangan Pendidikan Budaya dan Karakter Bangsa: Pedoman Sekolah. Jakarta: Kemendiknas, 2010.

[2] S. Muhibah, "Curriculum Development Model Islam Character Based Education ( Studies Analysis In SMKN 2 Pandeglang Banten )," Int. J. Sci. Technol. Res., vol. 3, no. 7, pp. 164-169, 2014.

[3] L. A. Jensen, "The Oxford Handbook of Human Development and Culture: an interdisciplinary perspective," Oxford Libr. Psychol., vol. 1, 2015.

[4] M. Borba, Building Moral Intelligence: The Seven Essentials Virtues that Teach Kids to Do the Right Thing. New York, NY: Random House, 2001.

[5] K. A. Eglinton, Youth Identities, Localities, and Visual Material Culture: Making Selves, Making Worlds, vol. 53, no. 9. 2013.

[6] Y. Sobri, "Keefektifan Kepemimpinan Kepala Sekolah Melalui Pendekatan Kecerdasan Emosional," J. Manaj. Pendidik., vol. 23, no. 1, pp. 34-47, 2010.

[7] R. Semiawan, "Peran Pendidikan dalam Pembangunan Karakter Bangsa. Peran Pendidikan dalam Pembangunan Karakter Bangsa," in Konferensi Nasional dan Workshop Asosiasi Psikologi Pendidikan Indonesia., 2010.

[8] Juharyanto, "Kepemimpinan unggul Kepala Sekolah Dasar Daerah Terpencil (Studi Multisitus pada Sekolah Dasar di Kabupaten Bondowoso)," J. Sekol. Dasar, vol. 1, no. Tahun 26, pp. 89-100, 2017.
[9] Burhanuddin \& Bafadal, Administrasi, Organisasi, dan Kekepala-sekolahan di SMTA. Malang: Proyek OPF IKIP Malang, 1991.

[10] Humada-Ludeke, The Creation of a Professional Learning Community for School Leaders. Rotterdam: Sense Publisher, 2013.

[11] Dimmock and Kong, Innovative School Principals and. 2005.

[12] Rivers/Houghton, Social Identities and Multiple Selves in Foreign Language Education. 2013.

[13] B. M. Radu, "Parental involvement in schools. A study of resources, mobilization, and inherent inequality," $J$. Comp. Reasearch Anthropol. Sociol., vol. 2, no. 2, pp. 103-115, 2011.

[14] M. D. Gall, J. P. Gall, and W. R. Borg, "An Introduction to Educational Design Research," East, 2007.

[15] T. A. O'Donoghue and K. F. Punch, Qualitative educational research in action: Doing and reflecting. 2003.

[16] P. C. Meijer, N. Verloop, and D. Beijaard, "Multimethod triangulation in a qualitative study on teachers' practical knowledge: An attempt to increase internal validity," Qual. Quant., 2002.

[17] Kementrian Pendidikan Nasional, "Rencana Strategis KEMDIKNAS 2010-2014 [KEMDIKNAS Strategic Planning 2010-2014]," 2010.

[18] M. Niqab, S. Sharma, L. M. Wei, and S. B. A. Maulod, "Instructional leadership potential among school principals in Pakistan," Int. Educ. Stud., vol. 7, no. 6, pp. 74-85, 2014.

[19] T. Lickona, "Teaching Respect and Responsibility. Reclaiming Children and Youth Journal," Reclaiming Child. Youth J., vol. 5, no. 3, pp. 143-151, 1996.

[20] K. Donlevy and K. D. Walker, Working through ethics in education and leadership. 2011.

[21] D. Baswardono, "2010. Pendidikan Karakter di Rumah. Peran Pendidikan dalam Pembangunan Karakter Bangsa.," in Konferensi Nasional dan Workshop Asosiasi Psikologi Pendidikan Indonesia, 2010.

[22] E. Sallis, Total Quality Management in Education. 1993.

[23] E. Lindberg and V. Vanyushyn, "School-Based Management with or without Instructional Leadership: Experience from Sweden,” J. Educ. Learn., vol. 2, no. 3, pp. 39-50, 2013.

[24] Hairiyah, "Konsep Manajemen Mutu Terpadu Dalam Pendidikan," Literasi, vol. VI, no. 1, pp. 99-110, 2015.

[25] J. An, Environmental Leadership Capacity Building in Higher Education. 2013.

[26] Q. C. Sim, "Instructional leadership among principals of secondary schools in Malaysia," Int. Res. Journals, vol. 2, no. December, pp. 1784-1800, 2011.

[27] C. K. Tanner, "Effects of the Use of Management Strategies on Stress Levels of High School Principals in the United States," Educ. Adm. Quarterly., vol. 27, no. 2, pp. 203-224, 1991.

[28] P. Duignan, "Forming Capable Leaders from Competence to Capabilities.," New Zeal. J. Educ. Leadersh., vol. 19, no. 2, pp. 5-13, 2004.

[29] L. Humphries, B. L. Parker, and R. J. Jagers, "Predictors of Moral Reasoning among African American Children: A Preliminary Study," J. Black Psychol., vol. 26, no. 1, pp. 51-64, 2000. 